\title{
Detection of Toxoplasma gondii by PCR and mouse bioassay in commercial cuts of pork from experimentally infected pigs
}

\author{
[Deteç̧ão do Toxoplasma gondii por PCR e bioensaio em camundongo em cortes comerciais \\ de carnes de suinos infectados experimentalmente]

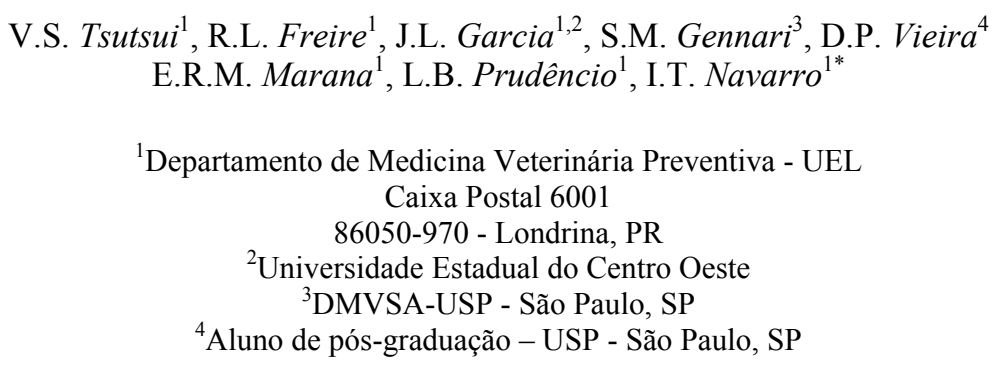

\begin{abstract}
The distribution of $T$. gondii in commercial cuts of pork (ham, tenderloin, spareribs and arm picnic) by PCR and bioassay from experimentally infected pigs, was evaluated. Eighteen mixed breed pigs were divided into two groups $(\mathrm{G})$. The $\mathrm{G} 1$ animals $(\mathrm{n}=10)$ were infected with $4 \times 10^{4}$ oocysts of the $T$. gondii VEG strain and the G2 animals $(\mathrm{n}=8)$ were used as control. Pigs of both groups were slaughtered at $59^{\text {th }}$ day after infection, and meat samples were collected for bioassay and PCR. All animals from G1 were positive by at least one or both tests, and all control animals were negative. T. gondii was identified in pork by mouse bioassay and PCR in $27 / 40(67.5 \%)$ and in $9 / 40(22.5 \%)$ of the evaluated samples, respectively. There were no statistical differences in the distribution of tissue cysts from commercial cuts of pork by bioassay $(\mathrm{P}>0.05)$. However, statistical differences were observed when mouse bioassay and PCR were compared $(\mathrm{P}<0.01)$.
\end{abstract}

Keywords: pork meat, mouse bioassay, PCR, Toxoplasma gondii

\section{RESUMO}

Avaliou-se a presença de T. gondii em cortes comerciais de carne suina (pernil, lombo, costela e paleta), por meio do bioensaio e PCR, em animais experimentalmente inoculados. Dois grupos $(G)$ foram formados. Os animais do G1 $(n=10)$ foram inoculados com $4 \times 10^{4}$ oocistos da cepa VEG e os do G2 $(n=8)$ permaneceram como grupo-controle, não inoculado. Todos os animais foram abatidos no dia 59 após a infecção, quando foram colhidas as amostras de carne para a realização das provas de bioensaio e da PCR. Todos os suínos do G1 apresentaram-se positivos a pelo menos um dos testes de diagnóstico ou a ambos, e os do grupo-controle permaneceram negativos. Não houve diferenças significativas em relação aos tipos de cortes comerciais e à presença do parasita no bioensaio $(P>0,05)$. O bioensaio foi capaz de detectar T. gondii em $27 / 40$ (67,5\%) amostras e a PCR em 9/40 (22,5\%). O estudo mostrou diferença entre o bioensaio e a PCR $(P<0,01)$.

Palavras-chave: carne suina, bioensaio em camundongos, PCR, Toxoplasma gondii

Recebido em 24 de maio de 2005

Aceito em 24 de novembro de 2006

*Autor para correspondência (corresponding author)

E-mail address: italmar@uel.br 


\section{INTRODUCTION}

Toxoplasma gondii is an intracellular parasite which can infect cells of human beings and all warm blood animals. It is a world wide protozoan parasite. Humans can become infected by ingesting either oocysts or raw and undercooked meat containing cysts (Garcia et al., 2004). Bradyzoites, located in tissue cysts, are able to survive for long periods within the host; the longevity of tissue cysts in pork can persist for more than two years (Dubey et al., 1998). This is important because pork is one of the most important sources of $T$. gondii infections in humans (Dubey, 1994).

Epidemiological studies in Brazil have showed that the seroprevalence of $T$. gondii in pigs varies from $9.6 \%$ to $54.1 \%$ (Vidotto et al., 1990; Garcia et al., 1999; Suárez-Aranda et al., 2000). This wide variation could be related to regional/geographical factors and the difference in production systems (Garcia et al., 1999).

The polymerase chain reaction (PCR) is an efficient molecular technique to detect the parasite animal and human tissues. This method is very sensitive, highly specific and rapid (Yai et al., 2003). Mouse bioassay is the principal method used to detected cysts in tissues, but it is arduous and expensive. The objective of this study was to evaluate the distribution of tissue cysts of $T$. gondii in commercial cuts of pork by PCR and mouse bioassay in experimentally infected pigs.

\section{MATERIAL AND METHODS}

The Toxoplasma gondii VEG and RH strains were used in this experiment. The VEG strain, a type III genotype, was used for pig infection. The $\mathrm{RH}$ strain, a type I genotype, was used as the antigen in the indirect fluorescence antibody test (IFAT).

The maintenance and care of experimental animals complied with the National Institute of Health guidelines for the humane use of laboratory animals. Eighteen mixed breed pigs between 6.5-7.5 weeks old, including females and castrated males, were randomly allocated in separate stables. An accommodation period of 6 days pre-experiment was used. Food and water were administered ad libitum. All pigs were serum negative (titer $<64$ ) by the $T$. gondii IFAT. Animals were divided in two groups, G1 (infected group, $\mathrm{n}=10$ ) and G2 (uninfected control group, $\mathrm{n}=8$ ). G1 was infected at day 0 with $4 \times 10^{4}$ oocysts of VEG strain by oral route. G1 pigs were treated at day 5 post-infection with an intramuscular dose of sulfadiazida $(3 \mathrm{mg} / \mathrm{Kg})$ and trimetoprim $(15 \mathrm{mg} / \mathrm{Kg}$. All pigs were treated because this promotes encystation of parasites and interrupts clinical symptoms (Alexander and Hunter, 1998). At death, muscle samples (ham, tender loin, spareribs and arm picnic) were collected to investigate $T$. gondii by mouse bioassay and PCR.

The presence of antibodies against $T$. gondii in serum samples of pigs and mice were measured by IFAT (Camargo, 1973) considering as positive pigs with titer $\geq 64$ and mice with titer $\geq$ 16.

Muscle samples (50g of ham, tenderloin, spareribs and arm picnic) from each pig were used to evaluate the presence of $T$. gondii cysts as previously described (Dubey, 1998). Briefly, each sample was homogenized in a blender for 30 seconds in $250 \mathrm{ml}$ of saline solution $(0.14 \mathrm{M}$ $\mathrm{NaCl}$ ). After homogenization, $250 \mathrm{ml}$ of pepsin solution was added and incubated at $37^{\circ} \mathrm{C}$ for $1 \mathrm{hr}$. The homogenate was filtered through two layers gauze and centrifuged at $1180 \mathrm{xg}$ for $10 \mathrm{~min}$. The supernatant was discarded and the sediment was resuspended in 20ml PBS (pH 7.2) and $15 \mathrm{ml} 1.2 \%$ sodium bicarbonate $(\mathrm{pH} 8.3)$ was added and centrifuged at $1180 \mathrm{xg}$ for $10 \mathrm{~min}$. The supernatant was discarded and the sediment was resuspended in $5 \mathrm{ml}$ of antibiotic saline solution $(1,000 \mathrm{U}$ penicillin and $100 \mu \mathrm{l}$ of streptomycin $/ \mathrm{ml}$ of saline solution) and inoculated subcutaneously into $3 \mathrm{mice}(1 \mathrm{ml} / \mathrm{mouse})$. Impression smears of lung from the mice that died were fixed in methanol, stained with Giemsa, and examined microscopically. Blood samples were obtained from mice that survived 60 days after inoculation. Brain of mice that survived were examined microscopically for $T$. gondii tissue cysts by squashing a portion of brain between a cover slip and a glass slide. Serum from each mouse was diluted at 1:16 and 1:64 and examined for anti-T. gondii antibodies using IFAT. A result was considered positive either by the detcetion of tissue cysts from brain samples or when a IFAT titer $\geq 16$ was observed. 
Muscle samples were digested as described above. The final sediment was resuspended in $3 \mathrm{ml}$ of TNE buffer $(200 \mathrm{mM} \mathrm{NaCl}, 20 \mathrm{mM}$ Tris, $50 \mathrm{mM}$ EDTA, pH8.0), and DNA was extracted as previously described (Silva and Langoni, 2001). Briefly, 3.6 $\mu 1$ of each sample was transferred to a microtube and diluted in $246.4 \mu \mathrm{l}$ of TNE and $250 \mu \mathrm{l}$ of TNE extraction buffer $(200 \mathrm{mM} \mathrm{NaCl}, 20 \mathrm{mM}$ Tris, $50 \mathrm{mM}$ EDTA, $0.6 \mathrm{mg} \mathrm{K}$ proteinase and $2 \% \mathrm{SDS}$ ). The samples were then incubated at $56^{\circ} \mathrm{C}$ for $90 \mathrm{~min}$, with frequent mixing $(15 \mathrm{~min})$ by inversion. The extracts were purified by standard phenol/ chloroform (Theil et al., 1981). Final volume $(20 \mu 1)$ was resuspended in $80 \mu 1$ of ultra pure sterile water, and it stored at $-20^{\circ} \mathrm{C}$ until PCR analysis.

DNA amplification of $T$. gondii was performed using the method described by Homan et al. (2000). Primers

TOX4 (5-CGCTGCAGGGAGGAAGACGAAAGTTG-3') and TOX5 (5'-CGCTGCAGACACAGTGCATCTGGATT$3^{\prime}$ ) were used, and these flanked a $529 \mathrm{bp}$ fragment of $T$. gondii DNA. PCR reaction was performed in a mixture containing $5 \mu \mathrm{l}$ of DNA extracted plus $20 \mu \mathrm{l}$ (final volume of $25 \mu \mathrm{l}$ ) of mixture of $0.5 \mathrm{mM}$ of each primer, $100 \mathrm{mM}$ dNTP (Invitrogen), $60 \mathrm{mM}$ Tris $\pm \mathrm{HCl}$ (pH9.0), $15 \mathrm{mM}\left(\mathrm{NH}_{4}\right)_{2} \mathrm{SO}_{4}, 2 \mathrm{mM} \mathrm{MgCl}{ }_{2}$, $0.5 \mathrm{U}$ Taq DNA polymerase (Gibco-BRL). Amplification of DNA from parasites were performed over 35 cycles in Eppendorf Mastercycler Gradienty, using the following cycling conditions: $7 \mathrm{~min}$ at $94^{\circ} \mathrm{C}$ for denaturation in cycle one, followed by 33 cycles on $60 \mathrm{~s}$ at $94^{\circ} \mathrm{C}$ for denaturation, $60 \mathrm{~s}$ at $55^{\circ} \mathrm{C}$ for annealing and $60 \mathrm{~s}$ at $72^{\circ} \mathrm{C}$ for extension, cycle 35 was followed by a final extension of $10 \mathrm{~min}$ at $72^{\circ} \mathrm{C}$. Aliquots of each
PCR were electrophoresed on 1\% agarose gel and ethidium bromede staining (Pereira et al., 1983).

Tachyzoites of RH strain were obtained from peritoneal fluid of infected Swiss Webstar mice. The material was passed thrice through a 26 gauge needle for purification and washed twice with $10 \mathrm{mM}$ phosphate buffered saline (PBS, pH7.5). After washing, tachyzoites were prepared at a concentration of $1.13 \times 10^{6}, 1.13 \times 10^{5}, 1.13 \times 10^{4}$, $1.13 \times 10^{3}, 113$ and $11,3 / \mathrm{ml}$. To evaluate sensitivity of the 529bp primers, DNA extraction and PCR of the cell suspensions were performed as described above.

Differences among test proportions were compared by chi-square $\left(\chi^{2}\right)$ test with Yates correction, using EpiInfo 6.01 statistical package. A P value of $<0.05$ was considered as significant.

\section{RESULTS}

The results of mouse bioassay and PCR are summarized on Table 1. Infected pigs had muscle samples recorded as positive by either or both PCR and mouse bioassay in every case, and there were no positive samples in G2 (control group). Mouse bioassay detected $27 / 40(67.5 \%)$ positive samples; being seven from tenderloin, nine from ham, five from spareribs and six from arm picnic. With PCR 9/40 (22.5\%) of evaluated samples were positive: three from tenderloin, four from ham, one from spareribs, and one from arm picnic. No statistical differences $(\mathrm{P}>0.05)$ were observed in the detection of $T$. gondii from commercial cuts of pork by bioassay. However, when the test were compared, differences were observed $(\mathrm{P}<0.01)$.

Table 1. Outcome of Toxoplasma gondii tissue cysts in commercial cuts of pork by mouse bioassay and polymerase chain reaction (PCR) obtained from infected pigs.

\begin{tabular}{|c|c|c|c|c|c|c|c|c|c|}
\hline \multirow{2}{*}{$\begin{array}{c}\text { Pig } \\
\#\end{array}$} & \multirow{2}{*}{ IFAT $^{1}$} & \multicolumn{2}{|c|}{ Tenderloin $^{4}$} & \multicolumn{2}{|c|}{$\mathrm{Ham}^{4}$} & \multicolumn{2}{|c|}{ Spareribs $^{4}$} & \multicolumn{2}{|c|}{ Arm picnic ${ }^{4}$} \\
\hline & & Bioassay $^{2,5}$ & $\mathrm{PCR}^{3,5}$ & Bioassay $^{5}$ & $\mathrm{PCR}^{5}$ & Bioassay $^{5}$ & $\mathrm{PCR}^{5}$ & Bioassay $^{5}$ & $\mathrm{PCR}^{5}$ \\
\hline & & $0(1) / 3$ & + & $3 / 3$ & + & $0 / 3$ & - & $0 / 3$ & - \\
\hline 2 & 256 & $2 / 3$ & - & $2(1) / 3$ & - & $2 / 3$ & + & $3 / 3$ & - \\
\hline 3 & 256 & $1(1) / 3$ & + & $1(2) / 3$ & - & $3 / 3$ & - & $3 / 3$ & + \\
\hline 4 & 256 & $0 / 3$ & - & $1(2) / 3$ & + & $0(1) / 3$ & - & $0(2) / 3$ & - \\
\hline 5 & 1024 & $0 / 3$ & - & $0(1) / 3$ & + & $0 / 3$ & - & $0(1) / 3$ & - \\
\hline 6 & 64 & $0(2) / 3$ & - & $0(2) / 3$ & + & $0(3) / 3$ & - & $0(3) / 3$ & - \\
\hline 7 & 256 & $0 / 3$ & + & $0 / 3$ & - & $0 / 3$ & - & $0 / 3$ & - \\
\hline 8 & 256 & $0(1) / 3$ & - & $0(2) / 3$ & - & $0 / 3$ & - & $0 / 3$ & - \\
\hline 9 & 256 & $2(1) / 3$ & - & $0(3) / 3$ & - & $0(2) / 3$ & - & $0 / 3$ & - \\
\hline 10 & 256 & $0(1) / 3$ & - & $0(1) / 3$ & - & $0 / 3$ & - & $0(1) / 3$ & - \\
\hline
\end{tabular}

${ }^{\mathrm{T}}$ Antibody titers of each pig, at slaughter day, in indirect fluorescence assay (IFAT) ${ }^{2}$ Results are expressed as number of mice positive for $T$. gondii of three mice inoculated with pepsin digest of pig tissue. Numbers in parenthesis indicate the number of mice with antibody titers $\geq 16$ (IFAT), but in which cysts were not seen in their brain; tissue cysts were seen in the other mice. ${ }^{3} \mathrm{PCR}$ was performed from pork. ${ }^{4} \mathrm{P}>0.05 ;{ }^{5} \mathrm{P}<0.01$ 
The sensitivity of PCR is shown in Fig. 1. PCR used in conditions of this experiment was able to detect the DNA of the parasite at a concentration of $10^{3}$ tachyzoites $/ \mathrm{ml}$.

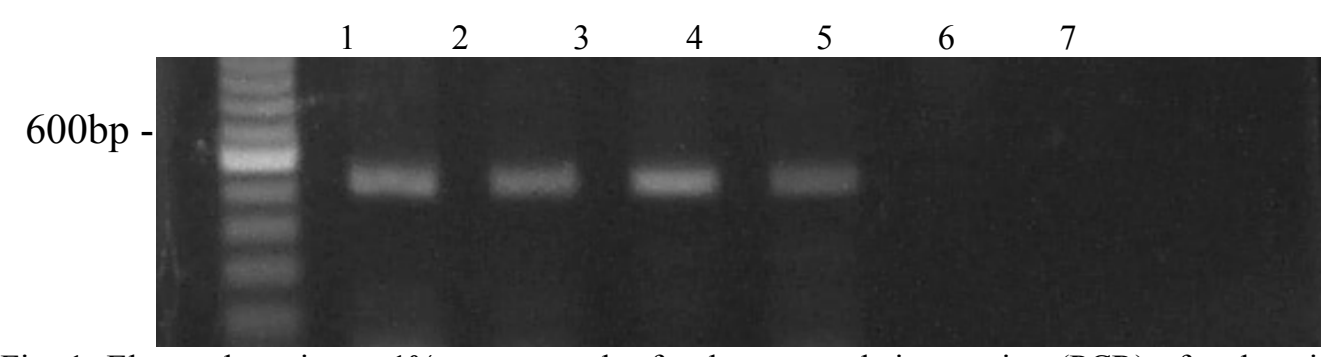

Fig. 1. Electrophoresis, on 1\% agarose gel, of polymerase chain reaction (PCR) of tachyzoite dilutions showing sensitivity of $529 \mathrm{bp}$ PCR. Lanes 1 to 6 represent dilutions: $1.13 \times 10^{6} ; 1.13 \times 10^{5} ; 1.13 \times 10^{4}$; $1.13 \times 10^{3} ; 113 ; 11.3$ of tachyzoites, respectively. Lane 7 : negative control.

\section{DISCUSSION}

Comparatively, bioassay detects viable parasites and PCR can detect DNA of parasites, even if the tissue is in a decomposed state (Yai et al., 2003). However, PCR may not express the risk of human infection (Aspinall et al., 2002).

Among the PCR targets used to detect $T$. gondii from blood, fluids and tissue samples, the B1 gene is the most widely used and includes a B1 nested-PCR. The used PCR amplified a $529 \mathrm{bp}$ fragment that is repeated $200-300$ times in $T$. gondii genome, and it was described as being more sensitive than B1 PCR (Homan et al., 2000). However, more DNA targets should be tested to ensure progress in the molecular diagnosis of toxoplasmosis (Chabbert et al., 2004).

Distribution of tissue cysts in commercial cuts has been described in pigs (Dubey, 1988). In the present study there were no differences in the detection of $T$. gondii among muscle samples. However, differences in distribution of tissue cysts are observed in other experimental animals (Dubey, 1997).

Mouse bioassay was more effective for the identification of parasite than PCR. During PCR analysis, DNA of the parasite was only detected in $22.5 \%$ of the samples examinated. This may due to the fact that PCR was able to produce a linear relationship between the relative amounts of PCR product and the number of tachyzoites in order of $10^{3}$ tachyzoites. Similar results $21.8 \%$ (7/32) were obtained by nested PCR when tissue samples of pigs challenged with oocysts were evaluated (Yai et al., 2003). Commercial meat products from the UK were evaluated for $T$. gondii by SAG2 amplification and the authors (Aspinall et al., 2002) found 27/71(38\%) positive samples.

During this study it was not possible to demonstrate the association between the distribution of $T$. gondii with commercial cuts of pork, while mouse bioassay was more sensitive than PCR.

\section{ACKNOWLEDGEMENTS}

We thank Prof. Dr. Selwyn Arlington Headley for critical reading of the manuscript and helpful suggestions.

\section{REFERENCES}

ALEXANDER, J.; HUNTER, C.A. Immunoregulations during toxoplasmosis. Chem. Immunol., v.70, p.81-102, 1998.

ASPINALL, T.V.; MARLEE, D.; HYDE, J.E. et al. Prevalence of Toxoplasma gondii in commercial meat products as monitored by polymerase chain reaction--food for thought? Int. J. Parasitol., v.32, p.1193-1199, 2002. 
CAMARGO, M.E. Introdução às técnicas de Imunofluorescência. Rev. Bras. Patol. Clin., v.10, p.143-171, 1973.

CHABBERT, E.; LACHAUD, L.; CROBU, L. et al. Comparison of two widely used PCR primer system for detection of Toxoplasma in amniotic fluid, blood and tissues. J. Clin. Microbiol., v.42, p.1719-1722, 2004.

DUBEY, J.P. Long-term persistence of Toxoplasma gondii in tissues of pigs inoculated with $T$. gondii oocysts and effect of freezing on viability of tissue cysts in pork. Am. J. Vet. Res., v.49, p.910-913, 1988.

DUBEY, J.P. Toxoplasmosis. J. Am. Vet. Med. Assoc., v.205, p.1593-1598, 1994.

DUBEY, J. P. Tissue cyst tropism in Toxoplasma gondii: a comparison of tissue cyst formation in organs of cats, and rodents fed oocysts.

Parasitology, v.115, p.15-20, 1997.

DUBEY, J.P. Refinement of pepsin digestion method for isolation of Toxoplasma gondii from infected tissues. Vet. Parasitol., v.74, p.75-77, 1998.

DUBEY, J.P.; LUNNEY, J.K.; SHEN, S.K. et al. Immunity to toxoplasmosis in pigs fed irradiated Toxoplasma gondii oocysts. J. Parasitol., v.84, p.749-752, 1998.

GARCIA, J.L.; GENNARI, S.M.; NAVARRO, I.T. et al. Toxoplasma gondii: isolation of tachyzoites rhoptries and incorporation into Iscom. Exp. Parasitol., v.108, p.40-46, 2004.

GARCIA, J.L.; NAVARRO, I.T.; OGAWA, L. et al. Soroprevalência do Toxoplasma gondii, em suínos, bovinos, ovinos e eqüinos, e sua correlação com humanos, felinos e caninos, oriundos de propriedades rurais do norte do Paraná, Brasil. Cien. Rural, v.29, p.91-97, 1999.
HOMAN, W.L.; VERCAMMEN, M.; DE BRAEKELEER, J. Identification of a 200 to 300 fold repetitive 529 bp DNA fragment in Toxoplasma gondii, and its use for diagnostic and quantitative PCR. Int. J. Parasitol., v.30, p.69-75, 2000.

PEREIRA， H.G.; AZEREDO, R.S.; LEITE, J.P.G. et al. Comparison of polyacrylamide gel eletrophoresis (PAGE), immunoelectron microscopy (IME) and enzyme immunossay (EIA) for the rapid diagnosis of rotavirus infection in children. Mem. Inst. Oswaldo Cruz, v.78, p.483-490, 1983.

SILVA, A.V.; LANGONI, H. The detection of Toxoplasma gondii by comparing cytology, histopathology, bioassay in mice, and the polymerase chain reaction (PCR). Vet. Parasitol., v.97, p.191-198, 2001.

SUARÉZ-ARANDA, F.; GALISTEO Jr., A.J.; HIRAMOTO, R.M. et al. The prevalence and avidity Toxoplasma gondii IgG antibodies in pigs from Brazil and Peru. Vet. Parasitol., v.91, p.23-32, 2000 .

THEIL, K.W.; MCCLOSLEY, C.M.; SAIF, L.J. et al. Rapid, simple method of preparing rotaviral double-stranded ribonucleic acid for analysis by poliacrylamide gel eletrophoresis. J. Clin. Microbiol., v.14, p.273-280, 1981.

VIDOTTO, O.; NAVARRO, I.T.; GIRALDI, N. et al. Estudos epidemiológicos da toxoplasmose em suínos da região de Londrina-PR. Semina, v.11, p.53-59, 1990.

YAI, L.E.O.; VIANNA, M.C.B.; SOARES, R.M. et al. Evaluation of experimental Toxoplasma gondii (Nicolle and Manceaux, 1909) infection in pigs by bioassay in mice and polymerase chain reaction. Braz. J. Vet. Res., v.40, p.227-234, 2003. 